\title{
Metode dan Model Pembelajaran Sejarah Kebudayaan Islam
}

\author{
Amalia Syurgawi ${ }^{1}$, Muhammad Yusuf ${ }^{2}$ \\ ${ }^{1}$ Sekolah Putri Darul Istiqamah Sulawesi Selatan, Indonesia \\ ${ }^{2}$ Sekolah Tinggi Agama Islam DDI Kota Makasar, Indonesia \\ 1amaliasyurgawi@gmail.com, 2yusufburhan8588@gmail.com
}

\begin{abstract}
Abstrak
Tulisan ini bertujuan untuk mengetahui model pembelajaran sejarah pendidikan Islam (SKI), tulisan ini merupakan kajian pustaka dengan menggunakan metode kulitatif deskripsi. Dari hasil penelusuran penulis menunjukkan bahwa sejarah kebudayaan Islam bahwa mata pelajaran yang diarahkan untuk memahami dan mengenal sejarah Islam. Adapun metode-metode yang dipergunakan dalam mempelajara sejarah Islam adalah metode ceramah, Tanya jawab, diskusi, demontrasi, timeline, concept map, role playing, active knowledge sharing. selanjutnya faktorfaktor yang perlu diperhatikan dalam pembelajaran yaitu tujuan, audiensi, fasilitas, keunggulan dan kelemahan. Impilikasi dari jurnal ini agar para pembaca dapat memahami metode dalam mengajarkan sejarah kebudayaan Islam.
\end{abstract}

Kata Kunci: model, metode, pembelajaran, SKI

\begin{abstract}
This paper aims to determine the learning model of the history of Islamic education (SKI), this paper is a literature review using the descriptive qualitative method. From the results of the author's search, it shows that the history of Islamic culture is a subject that is directed to understand and recognize Islamic history. The methods used in studying Islamic history are the lecture method, question and answer, discussion, demonstration, timeline, concept map, role playing, active knowledge sharing. Furthermore, the factors
\end{abstract}


that need to be considered in learning are objectives, audiences, facilities, strengths and weaknesses. The implication of this journal is that the readers can understand the methods in teaching the history of Islamic culture.

Keywords: learning, method, model, SKI

\section{PENDAHULUAN}

Aktifitas pendidikan dan pembelajaran adalah suatu aktifitas yang dilakukan dengan pola yang bersisitem dan bertujuan untuk memanusiakan manusia, serta mengajarinya untuk merencanakan dan mengatur masa depannya. Bercermin kepada sejarah, merupakan suatu kemestian yang harus dilakukan oleh manusia, guna mengetahui kegagalan dan keberhasilan umat-umat terdahulu, sesudah itu dia sendirilah yang menentukan masa depannya, sesuai dengan cerminan sejarah itu.

Ilmu sejarah merupakan bagian dari berbagai cabang ilmu yang mesti dipelajari oleh bangsa-bangsa dan generasi-generasi umat manusia. Ilmu sejarah senantiasa menarik minat orang banyak. Orang-orang biasa dan orang-orang yang tidak pintar juga ingin mengetahuinya, karena sebab inilah, maka pelajaran/ pengetahuan sejarah itu berkesan di dalam jiwa orang yang mempelajarinya, terutama dibidang sejarah kebudayaan Islam, yang merupakan budaya yang paling terbaik di masa pertenghan jika dibanding dengan kebudayaan bangsa-bangsa atau umat lainnya, seperti kebudayaan yunani, Persia dan Romawi Kuno. Inilah yang menjadi sebagian dari latar belakang penulisan ini.

Konsep pembelajaran modern menuntut siswa untuk mencari, memilih dan menemukan, menganalisis, meringkas, dan 
melaporkan hasil belajar. Model pembelajaran ini hanya dapat dilaksanakan dengan baik jika guru mampu mengembangkan strategi pembelajaran yang efektif. Oleh karena itu, kreativitas guru sangat dibutuhkan dalam memilih metode dan model pembelajaran yang efektif. ${ }^{1}$ Oleh karena itu, perlu dikaji pentingnya menggunakan beberapa metode dalam pembelajaran karena metode ini dapat sangat membantu dalam mencapai tujuan pembelajaran. sebagai pendidik atau Guru perlu merancang berbagai cara untuk menyampaikan materi pembelajaran, dengan perubahan metode yang tepat, siswa tidak akan bosan dengan materi pembelajaran yang disampaikan oleh pendidik atau guru, sehingga tujuan pembelajaran dapat tercapai dengan benar.

\section{METODE PENELITIAN}

Peneliti dalam penelitian ini menggunakan jenis penelitian kualitatif deskriptif dengan melakukan penelitian pustaka yakni analisis terhadap berbagai artikel, jurnal dan buku-buku yang yang terkait dengan tema penelitian. Adapun Pengumpulan data yang dilakukan oleh peneliti yaitu dengan menggunakan teknik dokumentasi dengan mencari tahu data-data penelitian dengan menaganalisis dokumen-dokumen terkait perihal yang peneliti teliti. Penulis dalam melakukan pengolahan data dengan melalui beberapa prosedur yakni diawali dengan pengumpulan data, selanjutnya melakukan reduksi data, kemudian mendisplay data

\footnotetext{
${ }^{1}$ Eni Riffiyanti, "Variasi Metode Pembelajaran Sejarah Kebudayaan Islam (SKI) Di MTs Miftahul Ulum Weding Bonang Demak," Jurnal Al-Fikri 2, no. 2 (2019): 2.
} 
dan langkah terakhir melakukan verifikasi data. Empat prosedur yang dilalui tersebut diharapkan menjadikan tulisan ini dapat bermanfaat bagi para pembaca.

\section{HASIL DAN PEMBAHASAN}

\section{Pengertian dan Tujuan Pembelajaran Sejarah Kebudayaan Islam}

Pengertian sejarah secara etimologis berasal dari kata arab "syajarah"yang mempunyai arti "pohon kehidupan" dan yang kita kenal didalam bahasa ilmiyah yakni History, dan makna sejarah mempunyai dua konsep yaitu: pertama, konsep sejarah yang memberikan pemahaman akan arti objektif tentang masa lampau. Kedua, sejarah menunjukan maknanya yang subjektif, karena masa lampau tersebut telah menjadi sebuah kisah atau cerita. $^{2}$

Sejarah kebudayaan (peradaban) Islam diartikan sebagai perekembangan atau kemajuan kebudayaan Islam dalam perspektif sejarahnya, dan peradaban Islam mempunyai berbagai macam pengetian lain diantaranya: pertama, sejarah peradaban Islam merupakan kemajuan dan tingkat kecerdasan akal yang di hasilkan dalam satu periode kekuasaan Islam mulai dari periode nabi Muhammad Saw sampai perkembangan kekuasaan Islam sekarang. Kedua, sejarah peradaban Islam merupakan hasil hasil yang dicapai oleh ummat Islam dalam lapangan kesastraan, ilmu pengetahuan dan kesenian. Ketiga, sejarah perdaban Islam merupakan kemajuan politik atau kekuasaan Islam yang berperan melindungi pandangan hidup Islam terutama dalam

2 Atabik Ali, Kamus Kontemporer Arab Indonesia, VIII. (Yogyakarta: Multikarya Grafika, 2003). 
hubungannya dengan ibadah-ibadah, penggunaan bahasa, dan kebiasaan hidup bermasyarakat.

Sedangkan SKI adalah singkatan dari Sejarah Kebudayaan Islam yang merupakan sebuah mata pelajaran pendidikan agama Islam yang diarahkan untuk mengenal, memahami, menghayati sejarah Islam, yang kemudian menjadi dasar pandangan hidupnya (way of life) melalui kegiatan bimbingan, pengajaran, latihan, keteladan, penggunaan pengalaman dan pembiasaan. ${ }^{3}$

Kuntowijoyo dalam Saidah menjelaskan bahwa ilmu sejarah merupakan ilmu yang terbuka. Hakikat dan kemandirian ilmu sejarah merupakan kekuatan yang dapat menjelaskan sejarah, sehingga perlu dibedakan penafsiran ilmu-ilmu alam dan ilmuilmu sosial dengan ilmu sejarah. Karena sejarah adalah ilmu yang berdiri sendiri. Kemandirian berarti memiliki filosofi sains Anda sendiri, masalah Anda sendiri, dan interpretasi Anda sendiri. ${ }^{4}$

Berdasarkan pengertian di atas, maka metode pengajaran SKI merupakan cara-cara yang ditempuh oleh para guru dalam pelajaran SKI agar tujuan pelajaran SKI dapat tercapai.

Ada pribahasa yang mengatakan "bangsa yang besar adalah bangsa yang menghargai pahlawannya". Atas dasar itulah betapa kedudukan sejarah amat penting dalam suatu Negara dan agama. Selain itu nilai sejarah (history) menjadi salah satu pondasi dasar

\footnotetext{
3 Admin, "Sejarah Kebudayaan Islam," SMP Negeri 10 Lahat, last modified 2010, http://alhafizh84.wordpress.com/2010/01/04/sejarah-kebudayaanIslam/.

4 Nur Saidah, "Eksplanasi Sejarah Dan Implikasinya Dalam Pengembangan Model Pembelajaran SKI Untuk MI," LITERASI (Jurnal IImu Pendidikan) 3, no. 1 (2016): 238.
} 
dalam pembentukan pendidikan di suatu Negara yang bertujuan untuk mengembang kan pendidikan secara optimal. ${ }^{5}$

Jadi dapat disimpulkan betapa pentingnya pelajaran tarikh dalam pendidikan formal untuk menciptakan dan membangun generasi yang meneladani perjuangan dan pencapaian para pahlawan Islam dalam membela dan menyebarkan agama Islam.

Sedangkan tujuan pembelajaran Sejarah Kebudayaan Islam sendiri sebenarnya berakar pada pengertianya di mana sudah di jelaskan dalam pembahasan di atas. Tentunya tujuan pembelajaran Sejarah Kebudayaan Islam sendiri tidak jauh-jauh dari mengambil pelajaran dari perjalanan sejarah umat-umat terdahulu, baik umat yang patuh kepada Allah dan Rasul nya maupun yang mengembangkan, kemudian di jadikan pegangan dan teladan untuk kehidupan sekarang dan masa yang akan datang, dalam rangka menggapai kebahagiaan hidup di dunia dan akhirat kelak.

Adapun tujuan-tujuan dari pembelajaran SKI berdasarkan referensi yang sudah kita himpun dapat disimpulkan yaitu: a) untuk mengetahui lintas peristiwa, waktu dan kejadian yang berhubungan dengan kebudayaan Islam, b) untuk mengetahui tempat-tempat bersejarah dan para tokoh yang berjasa dalam perkembangan Islam, c) untuk memahami bentuk peninggalan bersejarah dalam kebudayaan Islam dari satu periode ke periode berikutnya. Sedangkan manfaat dari mempelajarai Sejarah Kebudayaan Islam yakni: a) mengambil hikmah setiap kejadian di masa lampau untuk menembah ketakwaan kepada Allah, b)

5 Ahmad Warson, Kamus Al-Munawwir (Yogyakarta: PP Al-Munawwir Krapyak, 1984). 
mengambil pelajaran dari sejarah sebagai bahan pertimbangan ketika hendak membuat keputusan tentang suatu hal, c) mencari upaya antisipasi agar kekeliruan pada masa lalu tidak terjadi lagi pada masa yang akan datang, d) dapat memahami dan meneladani kisah-kisah yang baik pada zaman dahulu, e) menumbuhkan rasa cinta kepada kebudayaan Islam yang merupakan buah karya kaum muslimin masa lalu, f) Memahami berbagai hasil pemikiran dan hasil karya para ulama untuk diteladani dalam kehidupan sehari hari. ${ }^{6}$

\section{Metode dan Model Pengajaran Sejarah Kebudayaan Islam}

Pengetahuan tentang metode-metode mengajar sangat di perlukan oleh para pendidik, sebab berhasil atau tidaknya siswa belajar sangat tergantung pada tepat atau tidaknya metode mengajar yang digunakan oleh guru. Berbagai macam metode pembelajaran yang dapat digunakan oleh guru terhadap semua mata pelajaran. Salah satunya adalah mata pelajaran SKI. Metode yang dapat digunakan dalam mata pelajaran SKI diantaranya adalah:

Pertama, metode ceramah. Metode ceramah ialah suatu cara penyajian bahan pelajaran dengan melalui penuturan (penjelasan lisan) oleh guru kepada siswa. Dalam metode ceramah proses belajar mengajar yang dilaksanakan oleh guru umumnya didominasi dengan cara ceramah. Jadimelalui metode ceramah ini guru menceritakan/menyampaikan kejadian-

\footnotetext{
6 Uci Nurul, "Makalah Metode Pembelajaran SKI," Daftar Tugas Sekolah, last modified 2017, https://daftartugassekolah.blogspot.com/2017/04/makalahmetode-pembelajaran-ski.html.
} 
kejadian masa lampau dan menjelaskan hikmah apa yang bisa diambil dari sejarah tersebut. ${ }^{7}$

Kedua, metode tanya jawab. Metode tanya jawab adalah suatu cara mengelola pembelajaran dengan mengahasilkan pertanyaan-pertanyaan yang mengarahkan siswa memahami materi yang ada dalam pelajaran SKI. Metoda Tanya Jawab akan menjadi efektif bila materi yang menjadi topik bahasan menarik, menantang dan memiliki nilai aplikasi tinggi. Pertanyaaan yang diajukan bervariasi, meliputi pertanyaan tertutup (pertanyaan yang jawabannya hanya satu kemungkinan) dan pertanyaan terbuka (pertanyaan dengan banyak kemungkinan jawaban), serta disajikan dengan cara yang menarik. ${ }^{8}$

Ketiga, metode diskusi. Metode diskusi adalah suatu cara mengelola pembelajaran dengan penyajian materi melalui pemecahan masalah, atau analisis sistem produk teknologi yang pemecahannya sangat terbuka. Suatu diskusi dinilai menunjang keaktifan siswa bila diskusi itu melibatkan semua anggota diskusi dan menghasilkan suatu pemecahan masalah.

Keempat, metode demonstrasi. Metode demonstrasi adalah cara pengelolaan pembelajaran dengan memperagakan atau mempertunjukkan kepada siswa suatu proses, situasi, benda yang sedang dipelajari. Demontrasi dapat dilakukan dengan menunjukkan benda baik yang sebenarnya, model, maupun tiruannya dan disertai dengan penjelasan lisan. Demonstrasi

\footnotetext{
7 Ramayulis, Metodologi Pengajaran Agama Islam (Jakarta: Kalam Mulia, 2001), 20.

8 Marno and M Idris, Strategi Dan Metode Pengajaran: Menciptakan Keterampilan Mengajar Yang Efektif Dan Edukatif (Yogyakarta: Ar-Ruzz Media, 2008), 35.
} 
akan menjadi aktif jika dilakukan dengan baik oleh guru dan selanjutnya dilakukan oleh siswa. Metoda ini dapat dilakukan untuk kegiatan yang alatnya terbatas tetapi akan dilakukan terusmenerus dan berulang-ulang oleh siswa. ${ }^{9}$

Kelima, metode timeline (garis waktu). Metode ini tergolong tepat untuk pembelajaran sejarah karena di dalamnya termuat kronologi terjadinya peristiwa. Dengan metode ini, peserta didik bisa melihat urutan kejadian dan akhirnya juga bisa menyimpulkan hukum-hukum seperti sebab akibat dan bahkan bisa meramalkan apa yang akan terjadi dengan bantuan penguasaan Timeline beserta rentetan peristiwanya.

Timeline dipakai untuk melihat perjalanan dan perkembangan satu kebudayaan oleh karena itu dia bisa dibuat panjang atau hanya sekedar periode tertentu. Timeline untuk sejarah kebudayaan Islam bisa dibuat mulai dari zaman Jahiliyah menjelang Islam. hadir sampai pada saat ini; timeline juga hanya bisa dibuat menggambarkan perjalanan peristiwa dalam satu kurun atau periode tertentu. Ini adalah metode survey sejarah yang sangat baik karena peserta didik akan melihat benang merah atau hubungan satu peristiwa dengan peristiwa lainnya.

Adapun langkah-langkah pelaksanaan metode timeline adalah:

1) sampaikan tujuan pembelajaran dan kompetensi yang harus dikuasai peserta didik dalam pembelajaran hari itu,

2) tunjukkan pentingnya mempelajari sejarah melalui timeline,

\footnotetext{
${ }^{9}$ Ibid., 36.
} 
3) buat timeline dengan cara menarik garis lurus horizontal dan menuliskan waktu tertentu dan beberapa kejadian penting yang terjadi di dalamnya. Waktu berikutnya juga ditulis seperti cara titik waktu pertama dan begitu terus sampai pada waktu tertentu yang sesuai dengan materi pembelajaran.

Berikut ini adalah dua contoh timeline yang dibuat dengan cara yang sedikit berbeda pada masa nabi sampai menjelang hijrah. Timelineyang pertama ditulis dengan format satu tahun satu peristiwa penting.

Timelineyang kedua memungkinkan satu tahun memuat banyak peristiwa penting secara simultan.

4) jelaskan peristiwa-peristiwa penting yang terjadi pada tahun-tahun tertentu dan menjelaskan hubungannya dari tahun ke tahun,

5) adakan tanya jawab mengenai peristiwa-peristiwa dan hubungannya satu dengan yang lain,

6) buat kesimpulan dan

7) minta peserta didik untuk membuat timeline yang berhubungan dengan mereka masing-masing mulai dari lahir sampai saat ini.

Keenam, metode concept map (peta konsep). Peta konsep adalah cara yang praktis untuk mendeskripsikan gagasan yang ada dalam benak. Nilai praktisnya terletak pada kelenturan dan kemudahan pembuatannya. Guru bisa memanfaatkan peta konsep untuk dijadikan sebagai metode penyampaian materi sejarah. Penyampaian materi dengan peta konsep akan memudahkan siswa untuk mengikuti dan memahami alur sejarah 
dan memahami secara menyeluruh. Peserta didik sendiri nantinya yang akan membuat kaitan antara satu konsep dengan lainnya. Peta konsep sangat tepat dipakai untuk pembelajaran sejarah karena banyak konsep yang harus dikuasai oleh siswa untuk mengembangkan proses berpikir. Dengan peta konsep, peserta didik tidak akan mengingat dan menghafal materi sejarah secara verbatim, kata per-kata. Mereka punya kesempatan untuk membangun kata-kata mereka sendiri untuk menjelaskan hubungan satu konsep dengan lainnya. Di samping itu, Peta konsep bisa mengatasi hambatan verbal atau bahasa untuk menyampaikan gagasannya dan dalam saat yang sama bisa mengembangkan kemampuan berpikir tingkat tinggi yang pada akhirnya akan mendorong kemampuan verbalnya, penggunaan kata-kata untuk menyampaikan gagasannya.

Terkadang istilah Peta Konsep (Concept Map) disejajarkan dengan Peta Pikiran (Mind Map). Keduanya memang mempunyai kesamaan dalam hal pembuatannya; keduanya menggunakan cara kerja pembuatan peta. Sedikit perbedaan yang bisa digaris bawahi adalah bahwa Peta Pikiran lebih cenderung dipakai untuk menyampaikan gagasan-gagasan ilmiah yang menjadi kesepakatan umum, sementara itu, Peta Pikiran lebih bersifat personal, yaitu untuk menggambarkan ide-ide atau segala yang ada dalam pikiran seseorang. Peta pikiran merupakan metode yang sangan bagus untuk mencurahkan gagasan.

Langka-langkah pelaksanaan metode concept map dalam pembelajaran SKI adalah sebagai berikut:

1) jelaskan tujuan pembelajaran dan sebutkan jenis kompetensi yang harus dikuasai peserta didik, 
2) kaitkan materi yang akan dipelajari dengan keadaan peserta didik dan tunjukkan pentingnya mempelajari materi sejarah ini untuk kehidupan mereka,

3) tunjukkan pentingnya cara belajar dengan Peta Konsep dan berikan contoh-contohnya, artinya cukup tulisan setiap gagasan yang ada dalam pikiran ke dalam papan atau kertas. Minta semua peserta didik untuk menuliskan satu kata, konsep, gagasan, atau perasaan yang sekarang dirasakan. Dan tanyakan diakhir pelajar kenapa mereka menuliskannya dan diskusikan sebentar,

4) buat sebuah gambar yang melambangkan topik utama sekaligus merupakan garis besar di tengah atau di atas kertas kalau hubungan antar konsepnya bersifat hirarkis, seperti silsilah keturunan. Setiap kali membuat gambar atau garis, jelaskan maksud dan hubungannya,

5) buat garis tebal berlekuk-lekuk yang menyambung dari gambar di tengah kertas ke masing-masing cabang untuk setiap ide utama yang ada atau sebagai subjek. Cabang utama dalammind map melambangkan sub topik utama,

6) Beri nama pada setiap ide di atas atau boleh juga menambahkan gambar-gambar kecil mengenai masing-masing ide tersebut. Hal ini dilakukan untuk merangsang penggunaan kedua sisi otak,

7) dari setiap ide yang ada, tarik garis penghubung lainnya, yang menyebar seperti cabang-cabang pohon. Kemudian tambahkan buah pikiran ke setiap ide tadi. Cabang-cabang tambahan ini melambangkan detail-detail yang ada, 
8) buat kelompok untuk mendiskusikan Peta Konsep yang dibuat guru dipapan tulis dan minta salah satu dari masing-masing kelompok menjelaskan atau membaca Peta Konsep itu dalamkelompoknya secara bergantian.

Ketujuh, role playing (bermain peran). Bermain peran bisa berbentuk memerankan dialog tokoh-tokoh dalam sejarah atau memerankan diri atau kelompok sebagai ahli sejarah. Bentuk yang pertama bisa mengajak peserta didik untuk menjiwai karakter atau tokoh sejarah. Dengan cara ini, siswa merasakan dirinya sebagai aktor sejarah dan akan sangat berkesan bagi mereka. Dialog-dialog yang dipakai diusahakan untuk sederhana dengan tanpa meninggalkan gagasan-gagasan utamanya.

Adapun langkah-langkah pelaksanaan bermain peran dalam pembelajaran SKI adalah:

1) siapkan skenario beberapa hari minimal satu minggu sebelum tatap muka,

2) tunjuk beberapa siswa untuk mempelajari skenario dua hari sebelum kegiatan pembelajaran,

3) bentuk kelompok siswa yang anggotanya 5 siswa atau sesuai dengan kebutuhan,

4) beri penjelasan tentang kompetensi yang ingin dicapai,

5) panggil para siswa yang sudah ditunjuk untuk memainkan skenario yang sudah dipersiapkan,

6) minta masing-masing siswa duduk di kelompoknya, masingmasing sambil memperhatikan mengamati skenario yang sedang diperagakan,

7) beri kertas kepada peserta didik sebagai audiens setelah selesai pementasan untuk membahas masalah yang diangkat, 
8) minta masing-masing kelompok menyampaikan hasil kesimpulannya dan

9) berikan kesimpulan secara umum.

Kedelapan, active knowledge sharing (aktif berbagi pengetahuan). Ini adalah satu yang dapat membawa peserta didik untuk siap belajar dengan efektif dan melibatkan unsur afektif. Metode ini dapat digunakan untuk melihat tingkat kemampuan siswa di samping untuk membentuk kerja-sama kelompok. Adapun langkah-langkahnya adalah sebagai berikut:

1) siapkan sejumlah pertanyaan yang berkaitan dengan materi pelajaran yang akan diajarkan. Pertanyaan itu bisa menyangkut: a) Definisi suatu istilah b) Pertanyaan dalam bentuk Pilihan Ganda c) Mengidentifikasi tokoh sejarah d) Menanyakan sikap atau tindakan yang harus dilakukan e) Melengkapi kalimat, dll,

2) minta peserta didik untuk menjawab dengan sebaik-baiknya,

3) minta peserta didik untuk mencari teman yang dapat menjawab pertanyaan-pertanyaan yang tidak diketahui. Tekankan pada mereka untuk saling membantu,

4) Minta peserta didik untuk kembali ke tempat duduk masingmasing dan

5) Periksa jawaban siswa, klarifikasi kalau ada jawaban kurang tepat dan jawab pertanyaan-pertanyaan yang belum terjawab. ${ }^{10}$

10 W Sanjaya, Pembelajaran Dalam Implementasi Kurikulum Berbasis Kompetensi (Jakarta: Kencana, 2003), 45. 


\section{Faktor-Faktor yang harus Diperhatikan dalam Penetapan Metode yang akan Digunakan dalam Mengajar}

Dalam menentukan metode pengajaran seorang guru tidak boleh gegabah dalam penetapan metode yang akan digunakan hendaknya memperhatikan hal-hal sebagai berikut:

Pertama, tujuan yang hendak dicapai. Guru haruslah mengetahui dengan jelas tujuan yang hendak dicapainya, supaya metode dan media pendujungnya bias digunakan secara optimal dan maksimal.

Kedua, audiens (siswa). Seorang guru hendaknya memperhatikan Audiens (siswa) terlebih dahulu sebelum menentukan metode yang akan digunakan, karna jumlah dan karakter siswa,sangat berpengaruh pada umpan balik dan tujuan yang diharapkan seorang guru.

Ketiga, fasilitas. Fasilitas menjadi pertimbangan yang sangat penting dalam penetapan metode pengajaran, namun harus kita ingat fasilitas disini tidak hanya berkutat kepada materi semata namun non materi seperti waktu yang diberikan untuk seorang guru dalam menyampaikan materinya.

Keempat, keunggulan dan kelemahan metode tertentu. Tidak ada satu metode yang dapat dikatakan lebih baik karena metode-metode yang ada bisa bersifat tidak efektif apabila tidak tercapainya tujuan yang diharapkan atas dasar itulah hendaknya guru memperhatikan beberapa fakto-faktor yang telah di jelaskan di atas. ${ }^{11}$

\footnotetext{
11 Zuhairini and dkk, Metodik Khusus Pendidikan Agama (Malang: Biro Ilmiah Fakultas Tarbiyah IAIN Sunan Ampel, 1983), 20.
} 


\section{Ciri-Ciri Model Pembelajaran yang Baik}

Ada banyak model pembelajaran, tentu yang diinginkan adalah model pembelajaran yang paling efektif sehingga bias diterapkan dalam pembelajaran agar anak didik atau siswa menjadi lebih baik lagi. Namun, nyatanya tidak ada model pembelajaran yang paling efektif untuk semua mata pelajaran atau untuk semua materi.

Meskipun tidak ada model pembelajaran yang paling efektif, ada solusi untuk permasalaha pemilihan model pembelajaran ini. Pemilihan model pembelajaran untuk diterapkan guru dalam pembelajaran mempertimbangkan beberapa hal di antaranya: tujuan pembelajaran, sifat materi pelajaran, ketersediaan fasilitas, kondisis peserta didik, alokasi waktu yang tersedia. ${ }^{12}$

Ciri-ciri model pembelajaran yang baik dalam pengembangannya harus memperhatikan beberapa hal yaitu:

1) model pembelajaran tidak keluar dari pendekatan student center oriented dengan strategi discovery inquiry,

2) acuan dasar pengembangan adalah RPP yang dibuat guru dengan fokus: tujuan pembelajaran, kompleksitas materi ajar, metode pembelajaran dan alokasi waktu,

3) kegiatan yang akan dilakukan peserta didik dalam desain model pembelajaran harus merefleksikan metode pembelajaran yang dituliskan guru dalam RPP; Contoh, jika metode yang dipilih dan ditulis guru dalam RPP adalah pengamatan, maka langkah dalam model pembelajaran harus

\footnotetext{
12 Muryo Setyo, "Model Dan Ciri Pembelajaran Yang Baik Dan Efektif," Panduan Mengajar, last modified 2016, https://panduanmengajar.blogspot.com/2016/01/model-dan-ciripembelajaran-yang-baik.html.
} 
ada pernyataan " peserta didik melakukan pengamatan .... (lihat materi yang dikaji)"; Contoh lain, jika metode yang dipilih dan ditulis guru dalam RPP adalah diskusi, , maka langkah dalam model pembelajaran harus tertulis pernyataan, “ peserta didik mendiskusikan ... (sesuai dengan bahan diskusi),

4) persentase kegiatan peserta didik (belajar) lebih dominan daripada kegiatan guru,

5) eksplorasi, elaborasi, dan konfirmasi terakomodasi secara terpadu dan tersirat dalam rangkaian tahapan model pembelajaran yang dibuat,

6) model pembelajaran yang ditata hendaknya sistematis dan mampu menjawab keberhasilan pencapaian tujuan pembelajaran,

7) adanya keterlibatan intelektual dan atau emosional peserta didik melalui kegiatan mengalami, menganalisis, berbuat, dan pembentukan sikap,

8) adanya keikutsertaan peserta didik secara aktif dan kreatif selama pelaksanaan model pembelajaran,

9) guru bertindak sebagai fasilitator, koordinator, mediator, dan motivator kegiatan belajar peserta didik,

10) pemilihan alat, media, dan bahan pembelajaran harus tepat guna dan

11) apabila model pembelajaran yang akan diterapkan oleh guru dalam pembelajaran bukan produk sendiri melainkan adopsi atau adaptasi, maka pemilihan model yang akan digunakan 
harus mempertimbangkan acuan dasar dalam RPP ditambah dengan kesesuaian kondisi peserta didik. ${ }^{13}$

\section{KESIMPULAN}

Metode pembelajaran merupakan cara yang digunakan untuk mengimplementasikan rencana yang sudah disusun dalam bentuk kegiatan nyata dan praktis untuk mencapai tujuan pembelajaran. Adapun pentingnya belajar SKI yaitu untuk menciptakan dan membangun generasi yang meneladani perjuangan dan pencapaian para pahlawan islam dalam membela dan menyebarkan agama Islam.

Dalam pembelajaran SKI ada beberapa metode pembelajaran yang dapat digunakan untuk mengimplementasikan strategi pembelajaran, diantaranya: ceramah, demonstrasi, diskusi, tanya jawab, timeline, concept map, role playing (bermain peran), active knowledge sharing (aktif berbagi pengetahuan), dan sebagainya sesuai dengan materi apa yang ingin disampaikan ketika pelajaran SKI belangsung. Faktor-faktor yang harus diperhatikan dalam penetapan metode yang akan digunakan dalam mengajar: tujuan yang hendak dicapai, audiens (siswa), fasilitas, keunggulan dan kelemahan metode tertentu.

\section{DAFTAR PUSTAKA}

Admin. "Sejarah Kebudayaan Islam." SMP Negeri 10 Lahat. Last modified

http://alhafizh84.wordpress.com/2010/01/04/sejarahkebudayaan-Islam/.

13 Ibid. 
Ali, Atabik. Kamus Kontemporer Arab Indonesia. VIII. Yogyakarta: Multikarya Grafika, 2003.

Marno, and M Idris. Strategi Dan Metode Pengajaran: Menciptakan Keterampilan Mengajar Yang Efektif Dan Edukatif. Yogyakarta: Ar-Ruzz Media, 2008.

Nurul, Uci. "Makalah Metode Pembelajaran SKI." Daftar Tugas Sekolah. Last modified 2017. https://daftartugassekolah.blogspot.com/2017/04/makalah -metode-pembelajaran-ski.html.

Ramayulis. Metodologi Pengajaran Agama Islam. Jakarta: Kalam Mulia, 2001.

Riffiyanti, Eni. "Variasi Metode Pembelajaran Sejarah Kebudayaan Islam (SKI) Di MTs Miftahul Ulum Weding Bonang Demak." Jurnal Al-Fikri 2, no. 2 (2019): 1-10.

Saidah, Nur. "Eksplanasi Sejarah Dan Implikasinya Dalam Pengembangan Model Pembelajaran SKI Untuk MI." LITERASI (Jurnal IImu Pendidikan) 3, no. 1 (2016): 43.

Sanjaya, W. Pembelajaran Dalam Implementasi Kurikulum Berbasis Kompetensi. Jakarta: Kencana, 2003.

Setyo, Muryo. "Model Dan Ciri Pembelajaran Yang Baik Dan Efektif." Panduan Mengajar. Last modified 2016. https://panduanmengajar.blogspot.com/2016/01/modeldan-ciri-pembelajaran-yang-baik.html.

Warson, Ahmad. Kamus Al-Munawwir. Yogyakarta: PP AlMunawwir Krapyak, 1984.

Zuhairini, and dkk. Metodik Khusus Pendidikan Agama. Malang: Biro Ilmiah Fakultas Tarbiyah IAIN Sunan Ampel, 1983. 
Amalia Syurgawi, Muhammad Yusuf | MAHAROT Vol. 4, No. 2, 2020 